\title{
A polêmica entre Yosef ben Mattitiahou ha-Cohen e Titus Flavius Josephus
}

\author{
Alex Degan \\ alexdegan@yahoo.com.br
}

\begin{abstract}
Resumo: O presente artigo pretende oferecer uma leitura da sociedade judaica da Palestina do século I por meio de uma análise da vida e das obras do historiador judeu Flávio Josefo.
\end{abstract}

Palavras-Chave: Flávio Josefo; História; Judeus.

Eu, Josefo, filho de Matthias, um hebreu por raça, nativo de Jerusalém e sacerdote, que em princípio lutou pessoalmente contra os Romanos.

$B J^{1}, \mathrm{I}, 3$.

Sobre a vida de Flávio Josefo, possuímos apenas as informações que ele nos deixou em suas obras, já o qualificando como exceção dentre os historiadores do Mediterrâneo Antigo. Estas informações são muitas vezes contraditórias e em grande parte escritas para responder polêmicas contemporâneas e livrá-lo de acusações de traição. Ainda assim refletem um orgulho de sua origem que nem o exílio eliminou. Yosef ben Mattitiahou nasceu no primeiro ano do reinado de Calígula (Vita, 5), entre os anos de 37 e 38. Seu pai, Matthias (Vita, 7), pertencia ao grupo sacerdotal (kohanim), uma parcela da sociedade hierosolimitana importante para a estruturação política, econômica e cultural da Judéia. O orgulho em descender dos sacerdotes, particularmente da linhagem mais ilustre, foi expresso logo nas primeiras linhas de Vita:

* Doutorando em História Social, Mestre em História Econômica e Bacharel em História pela FFLCH da USP (orientador: Prof. Dr. Norberto Luiz Guarinello). Professor de História Antiga do Departamento de História da Universidade Federal do Triângulo Mineiro (UFTM) e membro do Laboratório de Estudos Sobre o Império Romano (LEIR) 
Minha família não é carente de distinção, já que descende dos sacerdotes. Cada povo possui um grau de nobreza; entre nós a participação no sacerdócio é marca de uma ilustre linhagem. Não só meus antepassados eram sacerdotes como também pertenciam à primeira das vinte e quatro classes uma peculiar distinção - e do mais nobre dos clãs constituintes. (Vita, 1-2).

Tal afirmação de Josefo é relevante, pois se baseia na divisão posta pelo livro bíblico I Crônicas 24, 7, apontando para a família Joiarib ${ }^{2}$. Seguindo a tradição, estas famílias pertenceriam à tribo de Levi, justamente as que não receberam terras nos tempos bíblicos por conta da missão de zelar e guardar a aliança entre o povo judeu e YHWH. Hierarquicamente organizados, esta aristocracia sacerdotal cultivava regras que asseguravam rigidez em suas relações de parentesco e consanguinidade, principalmente no tocante ao casamento, ação que se valia do auxílio de um arquivo situado em Jerusalém que entendia ser possível acompanhar a genealogia dos grandes sacerdotes desde os tempos bíblicos. Tal preocupação de Josefo em demonstrar sua nobreza hierocrática sugere que em sua época esta distinção ainda subsistia, apesar do descrédito sofrido pela aristocracia com as interferências da família de Herodes e dos romanos. Do lado materno ele nos informou que possuía sangue real (Vita, 2-6), se vinculando aos Asmoneus, linhagem real que gozou de alta estima na sociedade judaica da Palestina e que em nos relatos contidos no $B J$ e na $A J$ foram lembrados enquanto bons governantes e, ao menos nos primeiros tempos, como líderes justos. Observamos a existência de uma preocupação explícita de Josefo em ressaltar suas nobres origens familiares, qualificação que ele procurou transferir aos seus escritos na busca de legitimação.

Ao deixar a infância com sólida formação religiosa, iniciou um périplo pelas escolhas espirituais que o judaísmo comportava, defendidas pelos grupos dos fariseus, saduceus e essênios. Descrevendo três orientações, que no original está como hairesis ${ }^{3}$ (Vita: 10), observamos que o autor não retratou estes grupos de forma monolítica, mas de maneira dinâmica, sendo estes três comportamentos apresentados como legítimos na sociedade judaica, e não como parte de culturas marginais. Josefo conseguiu transitar livremente entre os grupos, sem registrar qualquer desconforto, sinalizando que esta escolha deveria ser comum entre seus contemporâneos (HADAS-LEBEL, 1991, p. 37). Citando as três correntes em três de suas obras ${ }^{4}$, se ocupou em detalhar mais o farisaísmo, sua escolha final, e o comportamento dos essênios. Sobre os primeiros, sabemos que em sua época eles constituíam o grupo mais numeroso e influente junto ao povo, reconhecidos por suas habilidades enquanto 
interpretes das escrituras e por suas ocupações políticas em Jerusalém. Outra característica importante se refere à crença na imortalidade da alma, atributo destacado pelo autor na espiritualidade farisaica. Conciliando livre-arbítrio com providência divina (BJ, VI: 310), sua interpretação farisaica exposta apontou o que os modernos estudos judaicos chamam de monoteísmo ético, que não admite que o homem apenas se limite a afirmar a sua fé no ser de Deus, exigindo engajamento na realização da sua vontade, no aperfeiçoamento da vida social e da estrutura moral segundo as normas do querer divino ${ }^{5}$. Nas obras de Josefo, a História parte da ação dos judeus, sempre procurando o equilíbrio entre os desígnios divinos e a liberdade humana ${ }^{6}$. Além destas observações, os fariseus descritos por Josefo se aproximavam de figuras como guias espirituais ou doutores da Lei, qualificações atribuídas aos rabinos antigos, populares e reconhecidamente sábios.

Josefo também foi generoso nas descrições dos essênios, com longas reflexões sobre seus costumes. De todos os grupos expostos, são os essênios os que formavam a comunidade mais homogênea e solidária, organizados em grupos presentes por todo território palestino. Os essênios da Guerra apresentavam o maior número de regras e privações para um iniciado, sujeito a um período de três anos de postulado. Ainda, no decorrer do levante contra Roma (66/70), eles se caracterizavam pela ausência do medo da morte, companheirismo e profundo zelo quanto aos costumes judaicos. Os essênios descritos em suas obras não se ligaram aos grupos políticos e sociais que se revoltaram no período e nem disputaram o comando de Jerusalém ou o controle do Templo. É possível que Josefo tenha procurado construir nos relatos sobre os essênios um paradigma do que ele entendia ser o bom judeu. Banhos purificadores, vida social comunitária, distância das escaramuças políticas de Jerusalém e atenção aos dizeres da Lei continuadamente foram assinaladas aos essênios. Dividiam com os fariseus a crença na imortalidade da alma, divergindo no tocante ao livre-arbítrio, pois os essênios descritos não se esforçavam em conciliar a liberdade humana com a providência divina, prevalecendo uma idéia central da divindade controladora do destino. Esta consciência da alma imortal e do desígnio divino, segundo Josefo, os permitia enfrentar a morte com um sorriso e sem desespero:

A guerra contra os romanos revelou sua força de caráter em todas as circunstâncias; com os membros espancados, retorcidos, queimados, cortados, submetidos a todos os instrumentos de tortura para arrancar-lhes alguma blasfêmia contra o legislador ou fazer-lhes comer um alimento proibido, negavam-se a esta ou aquela demanda, e nem se humilhavam ou 
vertiam lágrimas perante seus torturadores. Sorrindo em meio do suplício e zombando de seus carrascos, entregavam resignadamente suas almas, confiantes que as receberiam de volta novamente. (Guerra, II: 152-153).

O último grupo descrito por Josefo com interesse e reconhecimento foi o dos saduceus. Fechados mais em seus círculos familiares e sociais, conservadores no plano religioso e político, conferiam grande importância aos livros da Torah escrita, negando a imortalidade da alma e a ressurreição. Não acreditavam na divina providência e consagravam a máxima do livre-arbítrio, dizendo que "o homem escolhe livremente o bem ou o mal" (BJ, II: 164-166). Além de passar um tempo nestas três comunidades judaicas, Josefo nos diz que seu itinerário religioso comportou também um período de retiro no deserto, acompanhando um eremita chamado Banus. Em sua descrição das escolhas espirituais notamos a grande complexidade da sociedade judaica da Palestina do século I, comportando formas até mesmo contraditórias de se relacionarem com a divindade, com a Torah e com o Templo.

Em 56, então com dezenove anos, ele voltou para Jerusalém, dando início a sua participação na vida pública, optando pelos princípios dos fariseus. Em 64 foi para Roma, com o intuito de conseguir a liberação de alguns sacerdotes amigos, enviados como prisioneiros à capital por ordem do antigo procurador da Judéia, Félix (52/60). Por intermédio de Alítiro, um ator de origem judaica, Josefo conseguiu uma audiência com Popéia Sabina (Vita: 16), esposa do imperador Nero. Através da intervenção de Popéia ele obteve êxito na missão. É interessante notar em sua descrição do episódio que na primeira metade do século I Roma contava com uma pulsante comunidade judaica, já que foi nela que a embaixada palestina buscou apoio. Nesta ocasião jovem Josefo conheceu a maior cidade do Mediterrâneo, contemplando sua riqueza, organização e poder, lembranças que provavelmente voltaram como amargos avisos nos momentos iniciais do levante.

Também podemos deduzir que para compor esta embaixada Josefo falava um pouco de latim ou de grego. Pelas informações que ele nos deu, sabemos que conhecia aramaico, hebraico e a língua helena. Ao redigir suas obras em grego afirmou que "não poupou despesas" (BJ, I: 16), o que pode indicar que se valeu da ajuda de secretários para escrever. Nas descrições de sua educação no Vita só encontramos referências de estudos ligados à tradição judaica, embora tenha escrito em $A J$ que falava grego com sotaque (XX: 258). Consagrado pelo êxito de sua missão, poucos anos mais tarde ele foi designado como dirigente militar de uma das regiões mais problemáticas da Palestina judaica: a Galiléia. 
A Palestina judaica compreendia as regiões da Judéia, Galiléia e Peréia. Ainda encontramos cidades e vilarejos que cultivam laços políticos com Jerusalém na Iduméia, Samaria e Galadítida. Aos olhos do Estado romano a região se distinguia da província da Síria por seus dividendos e produtos agrícolas que proporcionava ao Império, como também pelos particularismos da religião dos judeus (SARTRE, 1994, p.383). A partir da conquista da região por Pompeu e Gabínio, entre 66 a.C e 55 a.C., os judeus palestinos não conquistaram nenhum período de liberdade política efetiva. $\mathrm{O}$ governo de Herodes representou muito mais um braço do poder romano do que uma alternativa judaica no complexo mundo oriental que Augusto reorganizou. Josefo registrou que para os judeus piedosos Herodes representou uma cruel liderança, pois não enxergavam nele as raízes judaicas profundas condizentes ao cargo, já que o rei era idumeu, população convertida recentemente, e filho de uma mãe árabe nabatéia. Herodes tampouco respeitava as formas tradicionais da arquitetura judaica, já que edificou em suas cidades e palácios uma estrutura mais próxima do mundo helenístico e romano, o que provocou espanto em seus súditos mais zelosos (GEIGER, 1990, p. 141-150). Até mesmo a reforma do Templo, iniciada por Herodes em 20 a.C. e concluída em 63 d.C., provocou reações de grupos de judeus de Jerusalém. Empregando cerca de 10.000 trabalhadores, a reforma foi encarada com ressalvas por alguns, como atestou a querela produzida pela instalação de uma águia dourada no portal principal do Templo, ação que violava abertamente o princípio que proibia a representação de seres vivos (descuido que não passou despercebido pelos judeus zelosos). Acima de tudo, Josefo registrou que os judeus não esqueciam que Herodes só se tornou rei por conta do apoio romano, tendo que teve que conquistar seu reino pelas armas entre 40 a.C. e 37 a.C., impondo o que Maurice Sartre qualificou de uma servidão tripla:

En resumen, a ojos de los judíos, obedecer a los Herodianos equivale a una triple servidumbre. Primero hacia Roma, pues nadie se engaña acerca de que todo el poder del rey depende de Roma. En segundo lugar hacia el príncipe cliente, brutal, codicioso e ímpio. En tercer lugar hacia los griegos cuya lengua, cultos y tipo de vida triunfan em todas partes con el apoyo de los príncipes y con menosprecio hacia los preceptos religiosos fundamentales. (SARTRE, 1994, p. 388).

A percepção negativa do governo de Herodes não se alterou com seus herdeiros, desprezados por grande parte da sociedade judaica, mesmo com a simpatia que Josefo registrou por Agripa I (que parece ter se beneficiado 
por uma opinião favorável dos fariseus). Nem mesmo Agripa I conseguiu equilibrar as tensões sociais judaicas, sendo que no ano 6 d.C. grande parte de seu reino se viu reduzido a um anexo da província da Síria, observada por seu governador. Um procurador romano ficou responsável pela administração direta da região, que pode apontar um aumento de distúrbios sociais e das preocupações romanas, sendo este procurador a autoridade que aplicava a arrecadação e justiça local. Em termos fiscais não sabemos se muita coisa se alterou, mas politicamente não encontramos melhorias, já que as queixas de desrespeitos antes dirigidas aos herodianos agora se voltavam aos romanos. Roma reconhecia a autoridade da Torah frente aos judeus, inclusive concedendo direitos como a dispensa militar e o respeito aos tesouros religiosos do Templo, embora, como assinalou Tessa Rajak (1978, p. 107-123), seja pouco provável que os judeus tenham recebido algum tipo de carta ou atenção especial que protegia sua cultura religiosa. Na verdade esta inclinação romana refletia mais uma política geral para com os povos dominados do que uma precaução particular em relação aos judeus. Entretanto, a regrada vida ditada pela Torah contrariava aspectos da vida pública e civil romana, o que produziu aborrecimentos e provocações tanto entre os gentios que serviam na região, quanto entre os judeus palestinos.

Neste contexto, a Judéia que Flávio Josefo iniciou sua vida política passava por muitas dificuldades internas, como o descrédito sofrido pelas classes dirigente, a grave crise econômica, crise agrária e um surto de banditismo. O sumo sacerdócio, instituição de grande prestígio, vinha sendo descaracterizado e esvaziado de seus significados frente aos judeus populares desde o governo de Herodes, pois este monarca indicou os sacerdotes que ocuparam o cargo. Com os romanos a situação não se alterou, sendo agora o sumo sacerdote o principal aliado que a política externa do Império procurou assentar seus contatos. A situação de desprestígio era tamanha que, durante o início da administração direta até 41, as vestes cerimoniais do grande sacerdote ficavam guardadas pelo procurador romano. Enfrentando um processo similar, o antigo Sanhedrin, um conselho de sacerdotes que funcionava em Jerusalém, também foi desacreditado diante o povo, sendo seus representantes vistos como indivíduos relacionados com a política imperial de Roma.

Embora a Palestina não fosse uma região notavelmente rica, sua produção agrícola era variada e bem desenvolvida (SAFRAI, 1994), com plantações de trigo, frutas e azeitonas, produções de azeites, de papiros, da pesca e da produção de mirra. Tradicionalmente a Judéia estruturava sua produção em pequenas propriedades familiares de camponeses livres 
(HORSLEY; HANSON, 1995, p.21), mas no início do século I a situação estava radicalmente diferente (GOODMAN, 1994, p.61). Enfrentando um aumento de população, a pequena propriedade se fragmentou mais ainda (as regras de herança judaicas privilegiavam o primogênito), gerando um contingente populacional que se encontrou sem um trabalho seguro. A parte destes camponeses sem terras permaneceu no campo, trabalhando como arrendatários e meeiros para médios proprietários ou nas grandes fazendas reais da época herodiana. Os que se dirigiram à capital poderiam encontrar uma ocupação com a reforma do Segundo Templo (GOODMAN, 1994, p.63). Josefo registrou em muitas passagens da Guerra, AJ e Vita que o banditismo rural $^{7}$ aumentou em proporções gigantescas, o que preocupou os administradores locais; de fato, se nos atentarmos ao que nos informam os Evangelhos e os textos do Talmude, a situação social era grave, pois os ricos foram na maioria das vezes retratados como figuras arrogantes e provocadoras, contrastando com a situação humilde dos camponeses. Contudo, seria uma temeridade afirmarmos que a única alternativa política visualizada pelos judeus palestinos era o levante contra as elites judaicas e romanas. Alternativas em curso oscilavam entre uma autonomia política vinculada ao Império e um isolamento radical, como no caso das comunidades do Qumran. De qualquer forma, as idéias de revolução só se desenvolveram com tanta força porque encontraram uma grande receptividade, já que parte dos judeus sonhava com a restauração de um tempo dourado de liberdade e concordância com suas leis ancestrais. As escrituras, com suas histórias edificantes e morais, proporcionavam muitos modelos para tal expectativa, já que na história antiga de Israel os justos e puros sempre encontravam recompensas.

Neste ambiente ainda se destacavam as produções de uma literatura apocalíptica e messiânica com uma visão escatológica da história. Identificar e classificar textos antigos dentro do gênero "Apocalipse" não é matéria fácil, mas em termos gerais podemos entender esta produção literária enquanto um tipo de literatura revelatória que coloca seu receptor humano em contato com o divino, estabelecendo uma realidade transcendente em que se extraem uma visão do Juízo Final e novas razões para cultivar esperanças ${ }^{8}$. Sem nos apegarmos aos debates dos aspectos particulares deste tipo de narrativa, devemos notar que tal produção reflete um desanimo gigantesco com o presente, fazendo seus escritores e consumidores voltarem suas esperanças e sonhos de mudanças para um futuro, que na tradição judaica, desde o exílio da Babilônia, esteve ligado ao fim dos tempos, ou dia de $\mathrm{YHWH}$, que marcaria a vitória dos justos com o início de uma Nova Aliança. Josefo não 
discutiu diretamente a literatura apocalíptica (DOBRORUKA, 2002, p.372391) e tampouco sinalizou estar interessado em fazer isto, mas ele não se omitiu em registrar que muitos grupos revolucionários cultivavam algum tipo de expectativa messiânica, levantando estes ideais quando pegavam nas armas e militavam entre os judeus palestinos. Em uma descrição de um grupo rebelde que Josefo qualificou como "Quarta Filosofia” (em relação aos essênios, fariseus e saduceus), esta relação entre política e religião foi colocada:

Durante sua administração [do cavaleiro Copônio], um Galileu chamado Judas incitou ao levante os nativos, embutindo-lhes a vergonha de consentir em pagar um tributo aos romanos e de submeter-se a outros senhores mortais, separados de Deus. Este homem era um sofista que fundou uma seita particular, que não possuía nada em comum com as outras. BJ, II: 117-119.

Ainda sobre esta relação entre sediciosos e expectativa religiosa, temos o registro, também no segundo tomo da obra, da ação de um "falso profeta" que teria incitado os judeus ao combate:

Mais bizarro ainda para os judeus foi o falso profeta egípcio. Um charlatão que dizia ter dotes de profeta conseguiu reunir trinta mil ingênuos e os conduziu ao deserto, até o Monte das Oliveiras. De lá se propôs a marchar contra Jerusalém e, depois de derrotar a guarnição romana, reinar como um tirano sobre o povo com o apoio dos partidários que o acompanhariam na invasão. BJ, II: 261-263.

Nestes dois fragmentos podemos observar que Josefo não fazia muita distinção entre as peculiaridades destes movimentos populares e apenas registrou superficialmente suas intenções religiosas. Seu juízo negativo foi o que prevaleceu, desqualificando estes atores sociais e lamentando a força persuasiva deles, mas não indo muito além. Todavia, é certo que este tipo de movimentação social refletia não só uma espera impaciente pela mudança, como também um descrédito forte e geral que as classes dirigentes sofriam: era uma impaciência viva expressa politicamente, socialmente e no pensamento religioso.

A Palestina judaica pré-revolucionária que Josefo encontrou apresentou uma nova categoria de rebeldes: os sicários. Ele os apresentou como uma espécie de grupo religioso fanático que, no início da década de 50, assassinava romanos e dirigentes judeus em plena luz do dia. Para Josefo os sicários e suas ações ajudaram a fomentar um clima de total terror e insegurança em 
Jerusalém, o que, nas palavras de Maurice Sartre (1994, p.402), engendrou um temor coletivo. Segundo Josefo:

Apareceu outra espécie de bandoleiros em Jerusalém, os chamados sicários, pois assassinavam em pleno dia e no centro da cidade. Misturavam-se especialmente com a multidão durante as festas, escondendo embaixo de suas roupas curtos punhais com os quais feriam seus inimigos. Caída a vítima, o assassino assumia a indignação da multidão, inspirando confiança e evitando suspeitas. Começaram por matar o sumo sacerdote Jônatas. Todo o dia ocorria alguma morte. O terror que se difundiu foi maior ainda que o mal. Todos esperavam receber a morte em qualquer momento, o mesmo que acontece na guerra. BJ, II: 254-257.

Para o historiador judeu o clima de terror instalado pelos sicários complicou ainda mais a situação dos dirigentes romanos e das elites judaicas frente ao povo humilde, pois com medo das ameaças as autoridades romanas passaram a reprimir qualquer manifestação popular, o que aumentou as tensões. Pressionada, a elite judaica vacilou em tomar alguma posição, demonstrando ainda mais sua ineficiência. Neste ambiente de profunda desconfiança mútua, Josefo iniciou sua carreira política, tendo que assumir uma posição em uma sociedade cindida. Martin Goodman (1994) entende que é neste jogo de forças que devemos buscar as causas imediatas para o conflito, pois as elites judaicas ao não encontrarem mais a opção de seguirem do lado romano, decidiram embarcar na rebelião. Para Goodman esta escolha foi tida como a única possibilidade da elite reaver seu poder, já que a impaciência do povo de Jerusalém e a explosão do banditismo no campo não toleravam mais excitações dos dirigentes. Lendo Josefo, entendemos que esta mudança ocorreu. Todavia, compreendemos que os dirigentes judeus não apenas se moveram pelo desejo de se preservar seu poder, mas principalmente buscavam estratégias de sobrevivência dentro de um universo político profundamente violento e hostil às famílias aristocráticas. Como ocorria em grande parte de seus domínios, Roma assentava as bases de sua política externa aliciando e cooptando as elites locais para trabalhar em seu proveito, não antes sem exercer pressão militar. A Palestina judaica padecia, nesta época, de duas grandes referências para o êxito desta forma de fazer política: uma elite reconhecida e uma rede de póleis. O país, essencialmente rural, enfrentava uma forte crise agrária e o banditismo crescia acentuadamente. A classe dirigente de Jerusalém procurou evitar o rompimento até quando teve meios para tal empresa. Somente quando, em 66, o procurador Géssio Floro tomou 17 talentos do tesouro do Templo (provocação que exaltou os 
ânimos em Jerusalém) esta associação política encontrou seu esgotamento. Em resposta, um grupo de jovens judeus organizou uma colheita de donativos ao "pobre Floro". Indignado com o chiste, o administrador romano reprimiu o populacho, instalando uma batalha generalizada nas ruas da cidade. Os moderados e dirigentes judeus conseguiram contornar a situação em Jerusalém e optaram por dirigir um gesto de amizade ao procurador; Floro respondeu ignorando o esforço e humilhou a elite. Diante deste comportamento o levante se reanimou e os dirigentes fracassaram em conter os ânimos. Josefo registrou que um grande número de membros da elite se exilou e um número pequeno foi assassinado. Agripa II foi repudiado em sua tentativa de esvaziar a rebelião, o Templo tomado e o sumo sacerdote Ananes chacinado. Diante dos acontecimentos o governador da Síria Céstio Galo enviou uma legião, a XII Fulminata, acrescida de tropas auxiliares para reconquistar a cidade. Seu intento falhou, e em uma confusa retirada dos romanos muitos morrem vitimados por emboscados preparadas pelos judeus. Segundo Josefo, foi só neste momento que os dirigentes hierosolimitanos se convenceram e, inclinados ao partido da guerra, se apressaram em ocupar sua direção, preenchendo todos os cargos de comando com o objetivo de preparar a defesa da nação para as investidas romanas.

Flávio Josefo reapareceu em sua narrativa neste ponto, sendo indicado para ocupar o cargo de general responsável pela região da Galiléia. É provável que Josefo gozava de algum prestígio entre os dirigentes de Jerusalém, pois a Galileia seria a primeira região a ser combatida pelos romanos e, historicamente, era a mais conturbada do país (HORSLEY, 2000). Assumindo seu cargo, se dedicou a fortificar e unificar a região, mas teve dificuldades em ser reconhecido pelos galileus, o que pode assinalar a desconfiança que setores populares tinham das classes dirigentes. Continuadamente associou os líderes populares que encontrou na região com grupos de bandidos e ladrões (RAJAK, 1983, p.84-85), relação especialmente dirigida ao seu inimigo João de Giscala. A desconfiança em torno de Josefo foi tão grande que ele chegou a ser investigado por uma comissão enviada, a pedido de João, de Jerusalém. Assim, segundo seus escritos, ele lutou praticamente em duas frentes: uma que visava fazer ser reconhecida sua autoridade e outra, igualmente assustadora, conduzida pelo experiente general Vespasiano.

A visão terrível que os cristãos nos legaram de Nero muita vezes nos impede de observar quando este imperador agiu de forma sensata. Ao saber da notícia do fracasso de Céstio Galo, Nero colocou um vitorioso general conduzindo três legiões ( $V$ Macedonica, X Fretensis e XV Apollinaris) para reabilitar a honra romana (BJ, I: 6). Contando com as tropas auxiliares 
que reis clientes disponibilizaram, as forças romanas contavam com um contingente variando de 45.000 e 50.000 homens! E aos 57 anos, veterano de batalhas contra germanos e bretões, Vespasiano desembarcou no litoral norte da Palestina, em território sírio, na primavera de 67.

Cercado na cidade de Yotapata, Josefo descreveu detalhadamente sua luta para defender os judeus, refletindo uma preocupação nítida do historiador em se defender de acusações de traição $0^{9}$ e em ressaltar suas qualidades enquanto estrategista. Tal trabalho dificultou tanto o cerco romano que instigou o ódio em suas fileiras e a admiração de seus comandantes, reconhecendo no general judeu um igual. Com a tomada da cidade Josefo se refugiou em uma caverna/cisterna com mais quarenta soldados; seu esconderijo foi descoberto e Vespasiano tratou de negociar a captura de seu habilidoso adversário. Neste episódio temos o nascimento de toda polêmica que até hoje envolve o historiador: Mireille Hadas-Lebel observou apropriadamente que enquanto muitos judeus se lançavam no conflito esperando nada menos que a morte, Josefo fez de tudo para preservar sua vida, batizando um capítulo de seu livro sobre o historiador como o título "A Arte de Sobreviver" (HADAS-LEBEL, 1991, p.107); Pierre Vidal-Naquet, numa introdução para uma tradução francesa do $B J$, sintetizou a discussão com o título "O Bom Uso da Traição" (VIDAL-NAQUET, 1980), apresentando Josefo como um verdadeiro homem intermediário, dialogando e transitando entre várias culturas não de uma forma artificial ou falseada, mas absolutamente natural, oferecendo um campo de visão dentro de outro campo, mostrando, no discurso romano da guerra, seu orgulho em ser judeu ${ }^{10}$. Foi neste momento que a tradição o reconheceu como Titus Flavius Josephus, esquecendo de Yosef ben Mattitiahou, grafando em seu próprio nome um hibridismo cultural que não devemos esquecer ao analisar seus escritos ${ }^{11}$. Convencido a se render por um tribuno chamado Nicanor, identificado como um amigo (BJ, III: 346), terminou tendo que argumentar contrariamente ao suicídio aos seus companheiros amotinados, ação que não alcançou êxito. Não sabemos se por obra da ficção ou do destino, viu-se inserido em uma "roda de suicidas", encerrado com apenas um companheiro e, como desejava fazer desde o princípio, com a capitulação aos romanos (BJ, III: 387-391). Sua prisão, muito desejada pelos invasores, foi reconhecida e admirada como um grande feito, afinal se tratava de um valoroso general (IGLESIAS, 1994, p.22). Entretanto, sua captura foi obscurecida na narrativa por sua predição ao general Vespasiano; crente de que o conquistador do povo eleito receberia o trono do Império, Josefo assumiu o papel de intérprete e mensageiro divino ao predizer a elevação da Casa Flávia à dignidade púrpura: 
Neste momento [após ouvir as palavras do tribuno Nicanor] recordou o que havia sonhado na noite anterior: Deus lhe havia antecipado as calamidades que no futuro sofreriam os judeus e o destino dos soberanos romanos. Ele estava habituado à interpretação dos sonhos, para, através deles, adivinhar os desígnios de Deus. Além disso, não ignorava as profecias dos livros sagrados, já que era um sacerdote, assim como seus ancestrais. Foi naquele momento que, possuído pelo espírito divino e evocando as terríveis visões dos sonhos passados, Josefo dirigiu para a divindade, silenciosamente, a seguinte oração: 'Já que a ti parece conveniente punir a nação dos Judeus, passando completamente tua fortuna para os Romanos, e a mim elegeu o espírito para predizer o futuro, eu consinto em viver e me entregar aos romanos. Mas toma a $\mathrm{Ti}$, como testemunho, que não sou um traidor, mas teu ministro'. $B J$, III: 351-354.

Nesta categoria de cativo tradutor de boas notícias, Josefo permaneceu preso em Cesaréia, mas em condições especiais. Provavelmente no cativeiro começou a tomar notas para redigir posteriormente o BJ. Permaneceu preso no acampamento romano por cerca de dois anos e meio (julho de 67 até dezembro de 69), assistindo a redução dos conflitos aos campos do Sul e cercanias de Jerusalém, o suicídio de Nero (68), a guerra civil em Roma (68-69) e, coroando sua libertação, a aclamação de Vespasiano ao trono do Império. Libertado, acompanhou os Flávios até Alexandria e, agora seguindo o príncipe-general Tito, retornou pela última vez a sua cidade natal. Não sabemos se por cinismo ou convicção (quiçá uma mistura dos dois) Flávio Josefo se mostrou convencido da mudança de fortuna divina, entendendo que por deslizes, abusos e profanações feitas pelos judeus, estes seriam merecedores de uma punição, cabendo esta tarefa aos romanos ${ }^{12}$. Em seu discurso aos amotinados de Jerusalém, tentando forçar uma rendição, nosso historiador argumenta aos seus compatriotas:

Que regiões escaparam do poder dos romanos, senão aquelas que, por serem ou muito frias ou muito quentes, não apresentam serventia? A fortuna se pronunciou em seu favor em todas as partes! Deus, que faz viajar consigo o império de nação em nação, agora reside na Itália. Existia a lei essencial, tanto entre os animais como entre os homens, de ceder aos mais poderosos e reconhecer a superioridade daqueles que a adquiriam por força das armas. Por esta razão os antepassados dos judeus, que superam vocês em alma, corpo e outras vantagens, cederam diante dos romanos. E nunca tomariam tal decisão se não houvessem confirmado que Deus estava do lado romano. BJ, V: 366-369. 
Tito sabia das dificuldades de se tomar Jerusalém, assim como estava informado da luta civil que se instalava dentro da capital (onde três partidos rebeldes disputavam a supremacia na condução da guerra). A solução mais acertada foi esperar os frutos da guerra civil e a ação devastadora da fome e do desespero enfraquecerem os rebalados. $\mathrm{Na}$ impressionante descrição que Josefo fez do sítio da Cidade Santa, a teia dos compromissos assumidos repercutiram na narrativa, pois mesmo sem manifestar censuras do lado romano ele expressou uma profunda dor com o triste desenrolar dos acontecimentos. No entanto, sua dor parece ter encontrado logo um consolo, se contentando em salvar a vida de alguns conhecidos, entre os quais seu irmão, e resgatar uns exemplares dos livros sagrados que se preservaram no incêndio do Templo (Vita: 418-421).

Após a destruição de Jerusalém acompanhou Tito até Roma, passando pela Síria e Egito. Chegando à capital do Império ele nos informou que recebeu das mãos do próprio imperador a cidadania romana, uma casa (que teria sido de Vespasiano) e uma pensão. Residindo na corte Flávia, ele se ocupou da redação de suas obras, todas discutindo temas judaicos. O primeiro livro publicado foi o Bellum Judaicum (BJ), livro dividido em sete tomos que tratam das causas imediatas do conflito contra os romanos, iniciando a narrativa nos tempos da rebelião dos Macabeus e encerrando-a no principado dos Flávios. Provavelmente sua obra seguinte foi a Antiquitates Judaicae ( $A J)$, um imenso livro composto por vinte tomos que tratam desde as origens do povo hebreu até o início da guerra com os romanos; a crítica estabeleceu sua publicação entre os anos 94 e 99 . Vita apareceu como um texto intermediário (publicado entre 94 e 100), talvez como um apêndice do tomo final de $A J$; um dos poucos exemplos do gênero na Antiguidade (IGLESIAS, 1994, p.39), Vita nos fornece a maior parte das informações pessoais reafirmando com grande ênfase o seu papel político enquanto general judeu (em seus 76 capítulos de um único tomo, Josefo dedicou mais da metade do livro ao assunto). Sua última obra conhecida foi Acerca da Antiguidade dos Judeus, ou Contra Apionem (CAp). Este livro foi escrito em resposta aos resmungos helenistas que questionavam a Antiguidade e a nobreza da civilização judaica (SAIZ, 1998, p.100), oferecendo aos historiadores um dos poucos compêndios de apologia do judaísmo feitos no Mundo Antigo (próximo aos trabalhos apologéticos de Filo de Alexandria). Publicada entre 96 e 100, Contra Apionem procurou responder calúnias e acusações antissemitas, demonstrando a nobreza judaica, o humanismo de sua civilização e sua superioridade em relação ao pensamento grego. 
Passando por quatro casamentos e gerando três filhos, Flávio Josefo terminou seus dias na capital do Império que destruiu sua nação, adotado pelos autores desta ação e, numa atitude paradoxal (RAJAK, 1983, p.185), cada vez mais apegado à tradição judaica. Deve ter representado uma figura obscura e estranha no seu tempo, pois para os romanos a lembrança de que ele comandou tropas na Galiléia deveria levantar suspeitas, assim como era acusado de traição pelos judeus. Suas últimas informações nos colocam no reinado de Domiciano, pois ele nos informou que durante seu reinado teve seus privilégios confirmados. Sem qualquer outra referência ou testemunho de sua existência, seguimos o laconismo de Mireille Hadas-Lebel (1991, p.234) quando ela observou que, "depois de 95 seu rastro se perde".

Assim como polêmica foi sua vida, inserido entre culturas e línguas distintas, sobrevivendo e transitando entre diferentes linguagens, polêmico também é o debate histórico em torno de sua personalidade e do valor de sua obra. Uma enorme historiografia, ampla nas perspectivas de análises, se desenvolveu, com rigor, desde o início do século XX. Em linhas gerais, observamos que as discussões sobre Josefo e seus livros reconhecem suas contribuições, principalmente entre os estudiosos da cultura judaica dos séculos I a.C. e I d.C., mas as concordâncias nas interpretações cessam aqui. Diferente da grande maioria das fontes escritas durante o século I d.C., Flávio Josefo experimentou e experimenta um contínuo julgamento moral, ultrapassando as linhas da crítica histórica; assim, continuadamente, o historiador judeu é discutido com enorme paixão, acalorados debates que, por vezes, afloram juízos sobre os rumos tomados pelo povo judeu no passado, no presente e, como não, no futuro.

É certo que em vida, entre seus compatriotas, ele já deveria sofrer uma desconfiança, sentimento que não deveria ser menor no lado romano. Josefo transitava entre mundos distintos, amargava suspeitas e escrevia sobre uma nação que não existia mais. No entanto, sabemos por Eusébio de Cesárea (História Eclesiástica, III: 9) que o historiador recebeu a honraria de ter uma estátua sua erigida em Roma, assim como a presença de suas obras na biblioteca da cidade.

Entre estas esferas é que se desenvolve a historiografia que trata o tema, particularmente entre os textos que debatem a religião e sociedade judaica, assim como as análises biográficas de Josefo. Ele próprio parecia ter consciência de tantas polêmicas, pois seus quatro livros se equilibraram entre defesas apaixonadas do judaísmo, negociações entre sua cultura dominada e a realidade imperial romana, condenações e apontamentos de culpados pela desgraça de Israel e a incomoda tarefa de sua defesa pessoal. 
The controversy between Yosef ben Mattitiahou ha Kohen and Titus Flavius Josephus.

Aвstract: This article intends to offer of the Palestine Jewish society through the analysis of the life and of the jewish historian Flavius Josephus.

KeYwords: Flavius Josephus; History; Jews.

\section{NOTAS}

1 Vamos adotar as seguintes abreviaturas para as obras de Flávio Josefo: $B J$ para A Guerra Judaica, AJ para Antiguidades Judaicas, CAp para Contra Apião e Vita para Autobiografia.

2 Em $A J$ VII 366, Josefo reafirma que esta divisão da aristocracia sacerdotal permanecia em sua época. Curiosamente, uma passagem de CAp II 108 registra a existência de apenas quatro classes sacerdotais, o que pode representar um erro na cópia latina do texto ou uma subdivisão dentro das famílias tradicionais (BARCLAY, 2007, p. 225).

3 Concordamos com o alerta de Anthony Saldarini (2005, p. 136-140) ao escrever que devemos tomar cuidados com o uso "indiscriminado e não técnico" que Josefo faz de alguns termos gregos. Ao aproximar realidades judaicas de uma percepção helenística o historiador judeu pode ter generalizado demais. Para Saldarini, "assinalá-los [as seitas judaicas] como associações gregas espontâneas ajuda pouco a esclarecer-lhes a natureza em virtude da variedade daquelas organizações. O mais próximo de uma qualificação destes grupos a que Josefo chega é quando ele os chama de haireseis. Hairesis, uma palavra grega mais conhecida em seu sentido pejorativo cristão de heresia, tinha um significado neutro e até positivo no uso grego não-cristão. Em razão do uso que Josefo faz deste hairesis, os estudiosos muitas vezes identificam os fariseus e os saduceus como escolas filosóficas de pensamento ou como seitas religiosas [...]. Uma hairesis era uma opção, coerente e baseada em princípios, por uma forma de vida, ou seja, por uma determinada escola de pensamento. Na visão dos povos antigos e sobremodo na de Josefo, uma vez que alguns princípios básicos de uma tradição tivessem sido aceitos, poder-se-ia esperar alguma diversidade, ou seja, alguma escolha de modos de vida e de pensamento particulares. As escolas filosóficas gregas eram, normalmente, formas de vida baseadas em certa compreensão do universo e da lei moral. Assim, Josefo usa hairesis a fim de descrever as grandes correntes de pensamento e práticas do judaísmo [...] de forma a suscitar respeitabilidade para o judaísmo e atestar a antiguidade e o valor de suas tradições" (SALDARINI, 2005, p. 136-137).

4 BJ, II 368-386; Vita 10-12; AJ XIII 171-173 e XVIII 11-22. 
5 Segundo o filósofo Walter Rehfeld (2003, p.10), “o Deus único do monoteísmo ético cria o homem à Sua semelhança: Não como os demais seres da natureza como algo acabado, pronto e determinado, mas com a capacidade de escolher, com o livre arbítrio que lhe permite tornar-se o que deveria ser, sempre de novo superar a si mesmo. Portanto, não importam ao monoteísmo ético o que o homem, individual e coletivamente, é, mas o que ele pode e deveria ser".

6 Para uma ótima síntese para a compreensão da História manifesta nos livros de Josefo, consultar: Dobroruka, 2007, p. 128-130.

7 Para uma boa problematização do banditismo social rural na Palestina do século I, consultar: Horsley; Hanson, 1995, p.69.

8 Sobre o tema da proliferação de literatura apocalíptica na Judéia do século I: Dobroruka, 2002, p. 372-391; Collins, 1979; Sartre, 1994, p. 397-399.

9 Cerca de 2/3 da Autobiografia tratam especificamente do período que Flávio Josefo permaneceu como general da Galileia, apontando uma preocupação em se defender de acusações de traidor da pátria dos judeus.

10 Na leitura de Pierre Vidal-Naquet (1980, p. 32): "Un intermediario offre scarso interesse quando si limita a essere il rappresentante d'un campo in seno a un altro campo; e Giuseppe difendeva di fronte agli ebrei la causa dei suoi padrón romani. Ma a una seconda lettura, il discorso indirizzato ai romani attesta l'immenso orgoglio che Giuseppe annetteva al fatto d'essere ebreo".

11 Na observação de Santo Mazzarino (1990, p. 97): "infine questa grande rivolta, che aveva travolto Gerusalemme, e distrutto il Tempio, e aveva inciso nella vita dello stesso Giuseppe. Ora egli era liberto dell'imperatore Vespasiano: non più semplicemente Giuseppe, ma Flavio Giuseppe".

12 Esta visão de Roma como um instrumento punitivo divino é analisada por muitos especialistas como uma influência do profeta Jeremias em Josefo. Sobre a vinculação de Josefo com Jeremias e sua idéia da providência divina: HadasLebel, 1991, p. 199-203; Vidal-Naquet, 1980, p. 175-178; Dobroruka, 2002, p. 377-379; Schwartz 1990, p. 34-35; Rhoads, 1976, p. 8-11; Rajak, 1983, p.92; Vidal-Naquet, 1996, p.77-107.

\section{FONTES}

Josephus. The Jewish War. London: Harvard University Press (Loeb Classical Library), 1989.

Josephus. The Life. Against Apion. Harvard University Press (Loeb Classical Library), 1997.

Josephus. Jewish Antiquities. Harvard University Press (Loeb Classical Library), 1970. 


\section{BIBLIOGRAFIA}

BILDE, P. Flavius Josephus between Jerusalem and Rome. Journal for the Study of the Pseudepigrapha Supplement Series 2, 1988.

Barclay, John M. G. Translation and Commentary. In: MASON, Steve (ed.). Flavius Josephus. Against Apion, Leiden: Brill, 2007.

Chevitarese, A. L.; C., Gabrieli. Judaísmo, Cristianismo, Helenismo. Itu, Ottoni Editora: 2003.

DobrorukA, V. Josefo, a literatura apocalíptica e a Revolta de 70 na Judéia. PHOÎNIX. Rio de Janeiro, no.8, pp.372/391, 2002.

Dobroruka, V. Historiografia helenística em roupagem judaica: Flávio Josefo, história e teologia. In: Joly, F. D. (org.). História e retórica: Ensaios sobre historiografia antiga. São Paulo: Alameda, 2007.

Geiger, J. Local Patriotism in the Hellenistic Cities of Palestine. In: Greece and Rome in Eretz Israel. Jerusalem: University of Haifa and Tel Aviv University, pp. 141/150, 1990.

Goodman, M. A classe dirigente da Judéia. As origens da revolta judaica contra Roma. 66-77 d.C. Rio de Janeiro: Imago, 1994.

Goodman, M. Textos, escribas e poder na Judéia Romana. In: Bowman, A. K.; Woolf, G. Cultura escrita e poder no mundo antigo. São Paulo: Editora Ática, 1998. Hadas-Lebes, M. Flávio Josefo. O judeu de Roma. Rio de Janeiro: Imago, 1991.

Horsley, R. A. Arqueologia, História e Sociedade na Galiléia. São Paulo: Paulus, 2000.

Horsley, R. A.; Hanson, J. S. Bandidos, Profetas e Messias. São Paulo: Paulus, 1995.

Iglesias, L. G. Introducción General. In: Flavio Josefo. Autobiografía. Contra Apión. Madrid: Gredos, 1994.

Mazzarino, S. Il Pensiero Storico Classico. Roma: Editori Laterza, 1990.

RAJAK, T. Josephus. Duckwoth: Londres, 1983.

RAJAK, T.; Noy, D. Archisynagogoi : Office, title and social status in the Grego-Jewish Synagogue. The Journal of Roman Studies. Paris, LXXXIII, p 75-93, 1993.

Rehfeld, W. I. Nas Sendas do Judaísmo. São Paulo, Editora Perspectiva, 2003.

RhoAds, D. M. Israel in Revolution. Philadelphia: Fortress Press, 1976.

SAFraI, Z. The Economy of Roman Palestine. London: Routledge, 1994.

SAIz, J. R. B. Introducción. In: Josefo. Autobiografia / Sobre la antigüedad de los judíos. Madrid: Alianza, 1987.

SAldarini, A. Fariseus, escribas e saduceus na sociedade palestinense: Uma abordagem sociológica. Tradução de Paulo Ferreira Valério. São Paulo: Paulinas, 2005. 
Sartre, M. El Oriente Romano. Madrid: Akal Ediciones, 1994.

Schwartz, S. Josephus and Judaean Politics. New York: E.J. BRILL, 1990.

VIDAL-NAqueT, P. Il buon uso del tradimento. Roma: Riuniti, 1980.

Vidal-Naquet, P. Los judíos, la memoria y el presente. Buenos Aires: Fondo de Cultura Económica, 1996. 